ISSN 0975-3311

Ushus JBMgt, 9, 7 (2010) 37-44

https:/ / doi.org/ 10.12725/ ujbm.16.4

\title{
BRAND PREFERENCE OF TWO - WHEELERS: PROBLEMS AND SATISFACTION LEVEL OF CONSUMERS
}

\author{
K. Kannusamy*
}

\begin{abstract}
Transport is an important aid for better hiring. Two - wheelers are becoming more popular especially among the people belonging to middle income group. There are wide choice of brands there is a stiff competition among the manufactures and marketers to aftract the attention of buyers. People prefer a specific model of motorcycle among different brands for various reasons like price, maintenance, fuel efficiency appearance, durability and resale value.

Today the two wheeler industry plays a significant role in the Indian economy. India is the second largest manufactures of two - wheelers in the world.

One of the very important characteristics of economic development is the transformation of luxury goods into necessary goods. In recent time one such goods, which has been highly demanded by the customers, is the motor cycle possessing a mechanical devices for conveyance is
\end{abstract}

* PG \& Research Department of Commerce, Gobi Avts \& Science College, Gobichettipalayam- 53. 
an indicator of good standard of living. Hence an attempt to be made on the Brand Preference of Two - Wheelers Problems and Satisfaction of consumers.

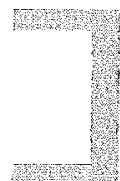

\section{Introduction}

The automobile is little more than a century old but the last fifty years have gone into refining the basis of engineering and fine - turning the technology. The Indian auto industry saw the completion of one full circle from being a net importer of vehicles of domestic manufacturer. India has been considered as a wider market for passenger automobiles and many foreign auto manufacturers are consistently trying to enter into the Indian market. The automobile industry was included in the first schedule of the industries act of 1951 .

\section{Two - wheeler industry in India}

Indian two - wheeler industry has acquired a new dimension during the last five years with intense competition and introduction of the state of art and technology changing the very complexion of the two - wheeler market while the owner of two wheelers have now a wide choice of models.

After the recession of 1992 - 93 the two - wheeler industries has shown brisk growth sustained over the last ten quarters. Even at a conservation $12 \%$ compounded annual growth rate, the industry reached on annual volume of sales of four million vehicles in the year 2000 .

"The automobile industry has a unique technological achievement and improvement over the other modes of surface transportation. Its development in the latter period ( $19^{\text {th }}$ century) and manufacturing later on a mass scale has been powerful stimulant to industrial growth in the economically developed countries of the west".

In India, particularly in urban areas, two wheeler is used for the variety of purposes mainly does connecting to the work. Visiting people, carrying loads, out door jobs like selling etc. In areas it enables people to travel more frequently to nearby towns for their daily needs. In other words, it has also become a valuable support for increasing productivity and profits, besides personal transportation. Two wheelers are classified into three types according to its usage. 


\section{Literature Review}

A study on "Brand Image among Refrigerators" conducted by Ranganathan et.al. (1995) with the objective to examine the image of the selected that most manufacturers seem by seal that their job is over once the sales deed is executed and the products is delivered. So they take little effort to solve the complaints received from the customers. They have also suggested that the manufactures should take steps to overcome the problems to avoid negative image of the brand.

A study conduced by Rajasekar (2002) in the topic "Fairness Creams study on markets Trends and Brand preferenced" was an attempt to know the levels of awareness and brand preference of fairness creams. They have concluded that the brand Fair \& Lovely tops the preference by $78 \%$ of awareness group, Fair ever with $66 \%$ and Emami's Natural Fairness $48 \%$..

A study conducted on "Brand Ectonsion" with preference to Arun (Hatson Aero products Limited)" by madhavi et.al., (2004) to identify the product most suitable for Pretension for the brand name "Arun". They have conducted that in case of chocolates brand "Arun most complete with brand parry's as the competitor a head from the study it was found that majority would buy the product but the company must maintain quality, price, etc.

A study conducted by Ravichandran and Narayanrajan (2004) conducted a study on "Factors determining no brand preference of Television with special reference to Thoothukudi District in Tamil Nadu" and analysed the relationship between of T.V. and brand preference.

\section{Objectives of the study}

1. To analyze the problems faced by consumers of Two-Wheelers.

2. To ascertain the level of satisfaction of consumers about their brand.

\section{Methodology and Sample Design}

The study is purely based upon primary data. The primary data were collected through personal interview with the help of a structured interview schedule. The present study is related to consumers of most familiar TwoWheelers such as Honda, Hero Honda, Yamaha, Bajaj, Tvs, Suzuki. To 
study the problems and satisfaction level of consumers of Two-Wheelers, 100 sample respondents were selected in the Gobichettipalayam Town by adopting Convenience sampling method. The sample consists of people such as agriculture, business employee and professional.

\section{Statistical Tools Used}

The primary data collected from 100 sample respondents are analyzed with the help of statistical tools such as Garrett ranking technique, Likert scaling technique and Chi-square test.

\section{Weighted Ranking Analysis}

As per this method, weighted score $(\mathrm{f} x)$ is calculated by multiplying the assigned score value $(x)$ and number of respondents $(f)$ is totaled and the rank is assigned on the basis of the total score. The factor scoring the highest value is considered as the most important factor. Rank is assigned on the basis of descending order to the total score.

\section{Problems Faced by the Consumers of Two - Wheelers}

Transport is an important aid for better hiring. Two - wheelers are becoming more popular especially among the people belonging to middle income group. There are wide choice of brands there is a stiff competition among the manufactures and marketers to attract the attention of buyers. People prefer a specific model of motorcycle among different brands for various reasons like price, maintenance, fuel efficiency appearance, durability and resale value.

On the basis of information collected from respondents through pilot study and consultation with experts it is found that two-wheelers users are facing the following problems like,

- Fuel Rate

- Mileage

- Poor quality of spare parts 
- High cost of spare parts

- Higher service charges

- High price

- Lesser quality

- Maintenance cost

- Colour

- Fuel consumption

Table 1 : Problems Faced by the Consumers of Two - Wheelers

\begin{tabular}{|l|c|c|c|}
\hline \multicolumn{1}{|c|}{ Problems } & Total score & Mean score & Rank \\
\hline Fuel Rate & 5493 & 54.93 & I \\
Mileage & 4958 & 49.58 & VI \\
Poor quality of spare parts & 5057 & 50.57 & IV \\
High cost of spare parts & 5182 & 51.82 & II \\
Higher service charges & 5098 & 50.98 & III \\
High price & 4895 & 48.95 & VII \\
Lesser quality & 4732 & 47.32 & IX \\
Colour & 4700 & 47.00 & X \\
Maintenance cost & 4830 & 48.30 & VIII \\
Fuel Consumption & 5021 & 50.21 & V \\
\hline
\end{tabular}

Source: Primary data

\section{Satisfaction Level of Two - Wheeler Consumers}

To measure the satisfaction level, factors such as price, quality, fragrance, advertisements, availability of different color, regular supply, brand image. A Five point Likert's scale was used. 
Table 2 : Classification of Sample Respondents According to their Level of Satisfaction

\begin{tabular}{|l|c|c|}
\hline \multicolumn{1}{|c|}{ Level of Satisfaction } & No. of Respondents & Percentage \\
\hline Satisfied & 76 & 76 \\
Dissatisfied & 24 & 24 \\
\hline Total & 100 & 100 \\
\hline
\end{tabular}

Source: Primary data

Table 2 reveals the over - all satisfaction of the sample respondents and it is found that majority of the Two - wheelers using consumers are having high level of satisfaction.

Table 3 : Relationship between Socio-economic Characteristics and Level of Satisfaction: Chi-square Analysis

\begin{tabular}{|l|c|c|c|c|}
\hline $\begin{array}{c}\text { Socio-Economic } \\
\text { Characteristics }\end{array}$ & $\begin{array}{c}\text { Table } \\
\text { Value@5\% } \\
\text { Level }\end{array}$ & $\begin{array}{c}\text { Calculated } \\
\text { Value x2 }\end{array}$ & $\begin{array}{c}\text { Degree } \\
\text { of } \\
\text { Freedom }\end{array}$ & Result \\
\hline Age & 7.815 & 1.219 & 3 & Insignificant \\
Marital status & 3.841. & 1.381 & 3 & Insignificant \\
Gender & 3.841 & 0.097 & 3 & Insignificant \\
Educational Qualification & 7.815 & 11.014 & 3 & Insignificant \\
Occupation & 9.488 & 2.130 & 4 & Insignificant \\
Type of Family & 3.841 & 3.412 & 4 & Insignificant \\
Number of Members & 5.991 & 2.498 & 2 & Insignificant \\
No. Earning Members & 5.991 & 1.893 & 2 & insignificant \\
Annual Income & 5.991 & 3.028 & 3 & insignificant \\
\hline
\end{tabular}

Source: Primary Data.

Table 3 reveals that the socio-economic factors of age, Marital status, gender, education, occupation, type of family, number of members, number of earning members, annual income are insignificantly with the satisfaction level of Two Wheeler consumers. 


\section{Recommendations}

- In the present study, it is found that the factor of Resale Value has been ranked by all the sample respondents as first and most significant factor to purchase of two-wheelers. Hence, it is suggested that manufacturers of two-wheelers to be taken effective steps to boost up image of their resale value. By doing so, two-wheeler manufacturers can increase their sales and profit.

- In the present study, it is suggested that the two-wheeler manufacturers have to take the necessary steps to improve the awareness among the people by taking the following measures.

- In the present study, it reveals that there is a though competition among the competitors. Hence it is recommended that each competitor must take appropriate steps to attract. The customers providing various features.

- In the present study, it is found that fuel rate and high cost of spare parts is an important problem of users of two-wheelers. Hence, it is suggested that manufacturers of two-wheelers should take necessary steps to reduce the fuel rate and spare parts price.

\section{Conclusion}

To day there are number of brands of two-wheelers are available in the market and they differ in price, quality, quantity, colour, style etc. In the present technological era, it can be easily said that all middle class people are also using this situation, two-wheelers producers are also come up with different names. But consumers prefer to purchase their favorable brands due to various reasons. It is obvious that, the quality, price, advertisement, style, colour, brand name etc. The present study reveals that majority of the sample respondents prefer to buy Hero Honda bike for its best price, quality, quantity, availability of spare parts, resale value etc, for this reasons, they can be easily marketed.

Hence, the manufacturer should pay special attention to the factors, like price, quality, quantity etc., make their business more successful and to satisfy the need of the consumers. 


\section{References}

\section{BOOKS}

- Gandhi J.C, Marketing, New Delhi: Tata McGraw - Hill Publishing Company Limited 1989.

- Gupta S.P, statistical methods, New Delhi; Sultan Chands \& Sons, 1997.

- Kothari C.R., Research Methodology, New Delhi : Wishwa Prakashan, 1998.

- Loudon L., and DellBitta J. Consumer Behaviour, New Delhi; McGraw - Hill Book Company, 1984.

- Mamoria C.B, and Joshi P.L., Principles and practice marketing in India, Allahabad, Kitab Mahal, 1984.

- Memoria, C.B., 1998, "Marketing Management", Kitab Mahal, Allahabad.

- Mishra M.N, Organisational Behaviour, Vikas Publishing House Private Limited, 2001.

- Neelamegham, Marketing in India cases and readings, Indian Management, Delhi.

- Pillai R.S.N, and Bagavathi, 1987, Prictices", S. Chand and Company Ltd., Ramnagar, New Delhi.

- Philip Kotler, Principles of Marketing, New Delhi : Prentice - Hall of India Private Limited, 2001.

- Sherlekar S.A., Marketing Management, Bombay, Himalaya Publishing House, 1984.

- Subbi Reddy T, Marketing Management, New Delhi; S.Chand \& Company Limtied, 1981.

II. Journals

- Indian Journal of Marketing

- Facts for you

- Kisan World

- Kurukshetra

- Southern Economist

III. Websites

- www.herohonda.com

- www.honda2wheelerindia.com

- www.bajajauto.com

- www.yamaha.com 